\title{
Sponge Bcl-2 homologous protein (BHP2-GC) confers distinct stress resistance to human HEK-293 cells
}

\author{
M Wiens ${ }^{1}$, B Diehl-Seifert ${ }^{1}$ and WEG Müller ${ }^{1}$ \\ 1 Institut für Physiologische Chemie, Abteilung Angewandte Molekularbiologie, \\ Universität, Duesbergweg 6, D-55099 Mainz, Germany \\ * Corresponding author: WEG Müller, Institut für Physiologische Chemie, \\ Abteilung Angewandte Molekularbiologie, Universität, Duesbergweg 6, 55099 \\ Mainz, Germany. Tel: +6131-3925910; fax: +6131-3924243; \\ E-mail:WMUELLER@mail.UNI-Mainz.DE
}

Received 4.12.00; revised 18.4.01; accepted 24.4.01 Edited by $\mathrm{C}$ Borner

\begin{abstract}
It is established that sponges, the phylogenetically oldest still extant phylum of Metazoa, possess key molecules of the apoptotic pathways, that is members from the Bcl-2 family and a pro-apoptotic molecule with death domains. Here we report on transfection studies of human cells with a sponge gene, GCBHP2. Sponge tissue was exposed to heat shock and tributyltin, which caused an upregulation of gene expression of GCBHP2. The cDNA GCBHP2 was introduced into human HEK-293 cells and mouse NIH-3T3 cells; the stable transfection was confirmed by the identification of the transcripts, by Western blotting as well as by immunofluorescence using antibodies raised against the recombinant polypeptide. HEK293 cells, transfected with GCBHP2, showed high resistance to serum starvation and tributyltin treatment, compared to mock-transfected cells. In contrast to mock-transfected cells, GCBHP2-transfected cells activated caspase-3 to a lower extent. Thus, sponges contain gene(s) involved in apoptotic pathway(s) displaying their function also in human cells. Cell Death and Differentiation (2001) 8, 887-898.
\end{abstract}

Keywords: Sponges; Porifera; invertebrates; Geodia cydonium; apoptosis; Bcl-2 homologous protein; HEK-293; NIH-3T3; tributyltin; heat shock

Abbreviations: aa, amino acid; DIG, digoxigenin; GAPDH, glyceraldehyde-3-phosphate dehydrogenase; nt, nucleotide; ORF, open reading frame; PCR, polymerase chain reaction; tbt, tributyltin.

\section{Introduction}

Until recent discoveries ${ }^{1,2}$ it was assumed that the physiological cell death is restricted to multicellular organisms, which have separate germ and somatic cells. ${ }^{3}$ Originally it was suggested to divide the physiological cell death into two processes: (a) 'programmed cell death', describing the developmentally regulated elimination of specific cells during embryogenesis, ${ }^{4}$ and (b) 'apoptotis', describing morphological changes of dying cells. ${ }^{5}$ While programmed cell death is characterized by the expression of new genes, apoptosis can proceed without new gene expression (reviewed in ${ }^{6}$ ). At present, these terms are used interchangeably; therefore, we apply the term apoptosis. In the last two years it has been elucidated that apoptosis is not restricted to Metazoa with separated cell lines but evolved already during the transition from the common ancestor of all metazoan phyla to the phylogenetically oldest metazoan taxon, the sponges [Porifera] (reviewed in $^{7}$.

Based on the identification and cloning of characteristic metazoan proteins, e.g. cell surface receptors (reviewed $i^{8}$ ), extracellular matrix proteins (reviewed in $^{9}$ ), immune molecules (reviewed $\mathrm{in}^{10}$ ), it became evident that all metazoans, including the sponges, are of monophyletic origin. ${ }^{11}$ This fact suggested also that the key molecules involved in apoptosis are already present in sponges. Subsequent studies elucidated that in sponges, with the two demosponges Geodia cydonium and Suberites domuncula as the most thoroughly investigated examples, polypeptide sequences exist which comprise high sequence similarities to members of the wider Bcl-2 family ${ }^{1,2}$ as well as to pro-apoptotic molecules containing the death domain. ${ }^{2}$

Members of the Bcl-2 family are defined by the conservation of two domains, termed $\mathrm{Bcl}-2$ homology domain-1 and -2 (BH1 and $\mathrm{BH} 2)^{12,13}$ The $\mathrm{Bcl}-2$ family comprises pro-survival molecules, e.g. $\mathrm{Bcl}-2^{14}$ as well as pro-death proteins, e.g. Bax. ${ }^{13}$ The number of the $\mathrm{Bcl}-2$ family members is rapidly growing. ${ }^{15}$ Structure analyses revealed that $\mathrm{BH} 1, \mathrm{BH} 2$ and $\mathrm{BH} 3$ are involved in binding to other proteins from the $\mathrm{Bcl}-2$ family. ${ }^{16,17}$ Hence, the members of the $\mathrm{Bcl}-2$ family interact with each other under formation of a complex network of homo- and heterodimers. ${ }^{18}$ It is assumed that the ratio of pro-survival versus pro-apoptotic dimers is crucial for the resistance of cells to apoptosis. ${ }^{19}$ While heterodimerization is not required for the pro-survival function ${ }^{20}$ such a process is thought to be essential for the pro-apoptotic activity, especially via the $\mathrm{BH} 3$ region. ${ }^{21}$ Members of the $\mathrm{Bcl}-2$ family that comprise only domains $\mathrm{BH} 1$ and $\mathrm{BH} 2$ belong to the pro-survival proteins, e.g. the GRS, ${ }^{22}$ the $\mathrm{A} 1^{23}$ and LMW5-HL. ${ }^{24}$

The first cDNAs encoding putative $\mathrm{Bcl}-2$ homologous proteins from animals evolutionary older than the triploblastic Metazoa have been identified from the sponges $G$. cydonium and $S$. domuncula. ${ }^{1}$ They are characterized by $\mathrm{BH} 1$ and $\mathrm{BH} 2$ domains and one transmembrane segment. It was the aim of the present study to elucidate the function of the putative $\mathrm{Bcl}-2$ homologous proteins in sponges. For these experiments a Bcl-2 molecule isolated from $G$. cydonium was chosen. Like the previous sponge 
Bcl-2's the new molecule, termed GCBHP2 (deduced polypeptide $\mathrm{BHP} 2$ _GC), comprises the $\mathrm{BH} 1$ and the $\mathrm{BH} 2$ domains as well as the transmembrane segment. ${ }^{1}$ Exposure of sponge cells to the organic derivative of the heavy metal tin, tributyltin [TBT] and heat shock causes an increased expression of GCBHP2. TBT also causes an $\left[\mathrm{Ca}^{2+}\right]_{\mathrm{i}}$ overload, cytoskeletal damage and mitochondrial failure (see $\mathrm{s}^{25}$ ); and it was already earlier found that TBT induces apoptosis in sponges ${ }^{26}$ and also in vertebrate cells. ${ }^{25,27}$ Here, the molecular marker septin was used to establish the selective expression of GCBHP2. Septin is a molecule involved in the orientation of the cleavage planes during cell division. ${ }^{28}$ In order to support the finding in the homologous system, HEK-293 cells as well as mouse $\mathrm{NIH}-3 \mathrm{~T} 3$ cells were stably transfected with the sponge gene encoding the putative $\mathrm{Bcl}-2$ homologous protein. HEK-293 cells have been selected for the studies since these cells are suitable for the investigation of the Fasinduced apoptotic pathway, ${ }^{29}$ and hence will also be used for further studies on the role of the sponge $\mathrm{Bcl}-2$ homologous proteins in this metabolism. In addition, transfection studies have been performed with NIH-3T3 cells. It was found that the sponge GCBHP2 gene confers resistance to HEK-293 cells towards the two inducers of apoptosis, TBT and to serum starvation ${ }^{25,30}$ after transfection. Furthermore, this report describes for the first time that a sponge gene causes a functional expression also in mammalian cells.

\section{Results}

\section{Cloning of the Bcl-2 homologous protein GCBHP2 from G. cydonium}

The complete cDNA GCBHP2 encoding the putative antiapoptotic protein BHP2_GC has been isolated after screening the G. cydonium cDNA library with GCBHP1 as a probe. The cDNA for the second Bcl-2 homologous protein (BHP) from G. cydonium is $935 \mathrm{nt}$ long (excluding the poly(A) tail). The potential ORF starting at $\mathrm{nt}_{110}$ to $\mathrm{nt}_{112}$ to the stop codon at $n t_{815-817}$ encodes a 235 aa long polypeptide (Figure 1A). The deduced protein sequence of this second BHP has a putative size $\left(M_{r}\right)$ of 25783 and an estimated isoelectric point ( $\mathrm{pl}$ ) of 6.38. The instability index has been computed to be 33.57 , indicating that BHP2_GC is a stable protein. ${ }^{31}$ Northern blot analysis performed with the sponge GCBHP2 clone as a probe yielded one prominent band of approximately $1.2 \mathrm{~kb}$, indicating that the full-length cDNA was isolated (see below). In addition, the exact transcription initiation site for GCBHP2 was determined experimentally by reverse transcription-PCR; it was found to be $109 \mathrm{nts}$ upstream of the putative start-methionine. Like the previously described BHP BHP1_GC also BHP2_GC comprises the two characteristic $\mathrm{Bcl}-2$ protein family domains $\mathrm{BH} 1\left(\mathrm{aa}_{125}\right.$ to $\left.\mathrm{aa}_{145}\right)$ and $\mathrm{BH} 2\left(\mathrm{aa}_{174}\right.$ to $\left.\mathrm{aa}_{193}\right)$ and the $\mathrm{COOH}$-terminal transmembrane segment $\left(\mathrm{aa}_{214}\right.$ to $\left.\mathrm{aa}_{234}\right)$; Figure 1A. Similarity searches for $\mathrm{BH} 1$ and $\mathrm{BH} 2$ domains were performed according to Yang and Korsmeyer. ${ }^{32}$ No similarities to $\mathrm{BH} 3$ and $\mathrm{BH} 4$ domains could be detected in BHP2_GC. ${ }^{20,33}$ Therefore, the number of potential helices towards the $\mathrm{NH}_{2}$-terminal end of BHP2_GC was determined. The computer analysis predicted two $\alpha$-helix regions (Figure 1A) spanning from $\mathrm{aa}_{24}$ to $\mathrm{aa}_{46}$ and from aa $\mathrm{a}_{94}$ to $\mathrm{aa}_{129}$.

The new sponge BHP protein identified has been aligned with the most similar polypeptides listed in the data banks. All belong to the Bcl-2 family comprising the $\mathrm{BH} 1$ and $\mathrm{BH} 2$ domains (data not shown). Highest similarity was found to the G. cydonium BHP1_GC with $10 \%$ of identical aa and $31 \%$ of similar aa. Somewhat lower are similarities to the vertebrate members of the Bcl-2 family, both promoting cell survival (pro-survival) and facilitating apoptosis (pro-apoptotic), as well as the Caenorhabditis elegans Ced- 9 sequence ( $\approx 8 \%$ identical aa $\approx 25 \%$ similar aa).

\section{Phylogenetic analysis of the sponge BHP domains}

The $\mathrm{BH} 1$ - (Figure 1B) as well as the $\mathrm{BH} 2$ domains (Figure 1C) from BHP2_GC were compared with the corresponding domains found in the most similar sequences of the $\mathrm{Bcl}-2$ family. The analysis revealed that the sponge molecules share (almost) all aa defined to be characteristic for $\mathrm{BH} 1$ domains $^{32,33}$ with other members of the Bcl-2 family, with $\approx 30-45 \%$ of identical aa and $\approx 50-72 \%$ of similar aa. In contrast, the similarity to the $C$. elegans domain is only $17 \%$ (identical aa) and $\approx 47 \%$ (similar aa). The phylogenetic tree (unrooted) constructed from the alignment (Figure $1 \mathrm{~B}-1$ ) from these $\mathrm{BH} 1$ segments, revealed that neither the sponge domains from BHP1_GC and BHP2_GC nor the BH1 domains from the pro-survival and pro-apoptotic sequences can be grouped to distinct clusters (Figure $1 \mathrm{~B}-2$ ).

In the same way the similarities of the sponge $\mathrm{BH} 2$ domains have been analyzed (Figure 1C). Based on the alignment (Figure $1 \mathrm{C}-1$ ) the sponge domains share $\approx 20-$ $30 \%$ of identical aa and $\approx 25-55 \%$ of similar aa with the corresponding pro-survival and pro-apoptotic sequences from vertebrates. Again the similarity to the $C$. elegans domain is low ( $9 \%$ identical aa and $\approx 18 \%$ similar aa). The unrooted tree shows again that no distinction between prosurvival and pro-apoptotic sequences can be made which is based on the aa similarity of the $\mathrm{BH} 2$ domains (Figure 1 C-2).

\section{Cloning of the sponge septin}

As a first marker for proliferation in sponges, the cDNA GCSEP1, encoding the putative septin SEP1_GC, was cloned; the sequence has been deposited (AJ293509).

\section{Preparation of recombinant $\mathrm{Bcl}-2$ homologous protein and antibodies}

GCBHP2 was expressed in $E$. coli and the purified recombinant oligohistidine-rBHP2GC fusion protein was prepared. The bacteria remained either uninduced or were induced by IPTG. The fusion protein was purified by affinity chromatography using Ni-NTA-agarose resin; the recombinant protein preparation is almost completely pure. A size 
of $23 \mathrm{kDa}$ was determined for the recombinant protein. The calculated $M_{r}$ for the deduced aa sequence of the cDNA BHP2_GC (inclusive the histidine tag) is $23.5 \mathrm{kDa}$ (not shown). Polyclonal antibodies have been prepared against rBHP2GC. Western blot analysis revealed only one band corresponding to rBHP2GC. Control studies were performed with antibodies which had been adsorbed with rBHP2GC; under those conditions no staining was seen (not shown).

\section{Exposure of cells from G. cydonium to selected stressors}

Two stressors have been chosen to study their effect on the expression of GCBHP2 in the homologous system: tributyltin (TBT) and heat shock.

Tissue samples were exposed to $1 \mu \mathrm{M}$ of TBT for up to $8 \mathrm{~h}$. Subsequently, RNA was prepared from the samples and subjected to Northern blotting to estimate the levels of gene expression. It was found that the steady-state level of septin (size: $1.4 \mathrm{~kb}$ ), which was chosen as a reference gene to monitor the viability and proliferation of the cells, did not alter, while the expression levels for the genes encoding the putative anti-apoptotic protein BHP2_GC GCBHP2 (1.2 kb) and the heat shock protein-70 GCHSP70 (accession number X94985; $2.1 \mathrm{~kb}$ ) increased drastically from $0 \%$ at time zero (not detectable under the conditions used) to $100 \%$ after incubation for $8 \mathrm{~h}$ in TBT (Figure 2A). At concentrations above $10 \mu \mathrm{M}$ of TBT the induction of the two 'stress-responsive' genes was abolished (not shown).

In a parallel line of experiments the tissue samples were treated with heat at $26^{\circ} \mathrm{C}\left(9^{\circ} \mathrm{C}\right.$ above the ambient temperature) as described under Materials and Methods. It was found again that the expression of the $1.2 \mathrm{~kb}$ GCBHP2 transcript and the $2.1 \mathrm{~kb} G C H S P 70$ transcript are significantly altered. While the expression of septin $(1.4 \mathrm{~kb})$ remained unchanged, the levels of GCBHP2 and GCHSP70 expression strongly increased from $0 \%$ (time zero) to $100 \%$ after an incubation for $5 \mathrm{~h}$ under heat stress (Figure 2B). If the tissue samples were treated at higher temperature stress, e.g. $14^{\circ} \mathrm{C}$ above the ambient temperature for $5 \mathrm{~h}$, no induction of gene expression was measured (not shown). These data show that the two stressors TBT and heat shock cause a selective expression of the genes encoding the stress proteins BHP2_GC and heat shock protein-70.

The degree of expression of GCBHP2 was also monitored on protein level by the Western blot technique. Tissue samples were treated both with TBT or heat as the protocols describe above. Both stressors caused an increase of BHP2_GC as checked. The data of the TBT induced expression are documented in Figure $2 \mathrm{C}$. It is evident that the amount of BHP2_GC strongly increased after $1 \mathrm{~h}$ of incubation. A prolonged incubation for $8 \mathrm{~h}$ even enhanced the degree of expression as can be deduced from the strength of the $26 \mathrm{kDa}$ band [calculated size of the sponge protein: $M_{r} 25783$; see above] reflecting the BHP2_GC protein.

\section{Transfection of sponge GCBHP2 into mammalian cells}

The cDNA construct with the G. cydonium GCBHP2 was introduced into human HEK-293 cells. Stable transfectants were selected by geneticine, G418, and the expression of GCBHP2 was confirmed by the following techniques.

Identification of the transcripts Using the primers described under Materials and Methods, the $590 \mathrm{bp}$ long PCR product, reflecting the expression of GCBHP2, could be identified in transfected cells; in mock-transfected cells this band was missing. As a control, the expression of the glyceraldehyde-3-phosphate dehydrogenase (GAPDH) gene was determined; the expected 471-bp long PCR fragment was obtained both in transfected and non-transfected cells (data not shown).

Western blotting Antibodies, raised against the recombinant G. cydonium BHP2_GC, rBHP2GC, were applied to demonstrate the presence of the expressed sponge gene in transfected HEK-293 cells. The Western blot analysis of the extracts from transfected cells revealed one band corresponding to a size of $26 \mathrm{kDa}$ (data not shown). Control studies have been performed with an extract from mocktransfected cells. In this sample no protein was recognized by the PoAb-BHP2GC antibody.

\section{BHP2_GC expression in HEK-293 cells and NIH-3T3 cells}

GCBHP2 was expressed in HEK-293 cells. Stable transfectants changed their pattern of attachment to the solid phase, irrespectively if the cells were plated on plastics or glass. Control cells, transfected with the pcDNA3 plasmid without insert were shown to spread homogeneously over the surface of the plates. In contrast, the HEK-293 cells transfected with the plasmid containing GCBHP2 clump together and form 'foci'-like clusters (data not shown).

The expression of GCBHP2 was demonstrated by immunofluorescence. HEK-293 cells which had been stably transfected with the expression plasmid lacking GCBHP2 did not show any staining with the antibody, PoAb-BHP2GC, raised against the recombinant rBHP2GC (Figure $3 a, b$ and e,f). However cells which had been stably transfected with the expression plasmid containing GCBHP2 are brightly stained using PoAb-BHP2GC (Figure $3 c, d$ and $g, h$ ).

In a parallel series of experiments $\mathrm{NIH}-3 \mathrm{~T} 3$ cells were stably transfected with GCBHP2. Subsequently, the cells were stained both with the monoclonal anti-Hexa-His antibody and with the affinity purified polyclonal antibody against p33/gC1qR (a mitochondrial marker protein), to obtain a more detailed intracellular location in cells larger than HEK-293. The results show that the distribution of the staining with the PoAb-BHP2GC and with anti-p33/gC1qR is almost identical (Figure 4); however a distinct localization of BHP2_GC on the surface of the mitochondria can not be deduced as reported earlier $\left(\mathrm{see}^{34}\right)$. 
A BHP1_GC : MATGSLTCYSFTHSPRSVPKRHQLHQRASPKQQRAVRGGGEKRMSDDPAVVQAEFLAKDVVEYLLN : 66
BHP2_GC : --

helix-1

BHP1_GC : KEGMSVHGYTDVLPGHLRKVPRKERQCTHEP SFEQARRQIVCGCQCTMHQHGVEIEQICMKV---- : 128 BHP 2 GC : DNGLSCGGR-EYWREPASTVG-AASDGLSEEERRTAADAAERMT AVIAGTPG IAVERWVRDFRRGG : 107

\section{helix-2}

BHP1_GC : -DVGDEHLYSWVKEALAT ITEEEPKWGRLVSLFVAAYYLCKRICDEEGEGSEKIDSVIGNLASFLK : 193 BHP2_GC : WDVTPDNYESEFREVERRTESDGVHWGRV IAFLAFSMSFAAYVNSRGIDGG--AYSVFULTLRVLA : 171

BHP1 GC: : ENAVPWVVERGGFAGVLYGTNIKPQAAGAAVEDCKSD-YTKASLFVTALGLGAAVVVGTIIGR- : 255 BHP 2 GC : DSLADF IQRENGWRGF IVYADTLLRAOG STPPQHQTRGVWDAVAGIGVIGVGTLLALGMRQAFS : 235

$\mathrm{BH} 2$

B-1

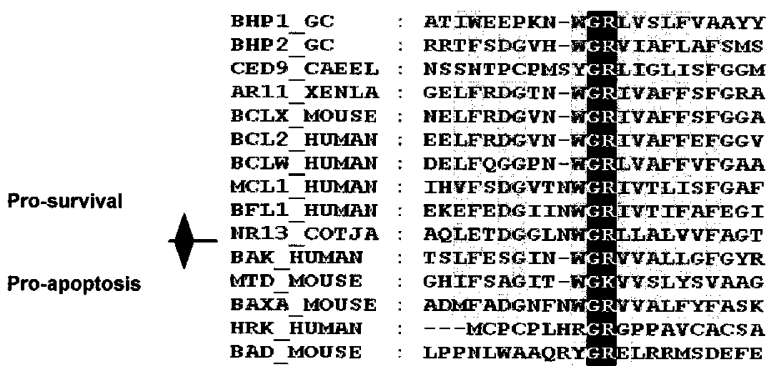

C-1

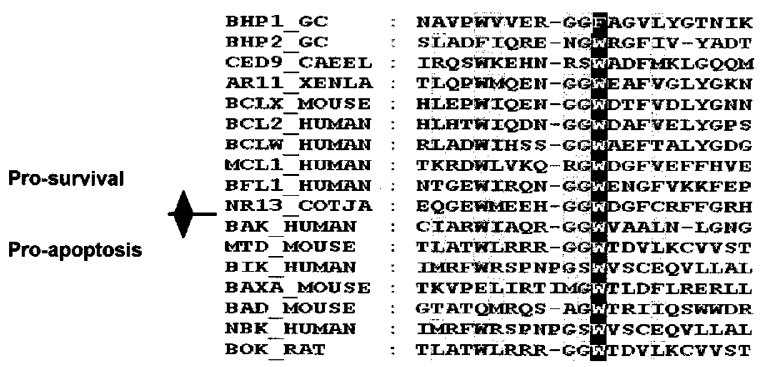

B-2

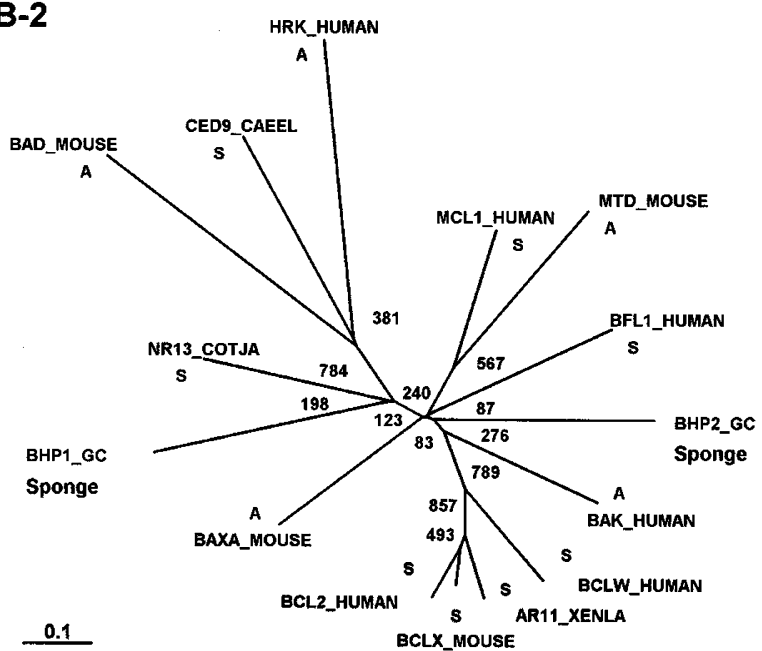

C-2

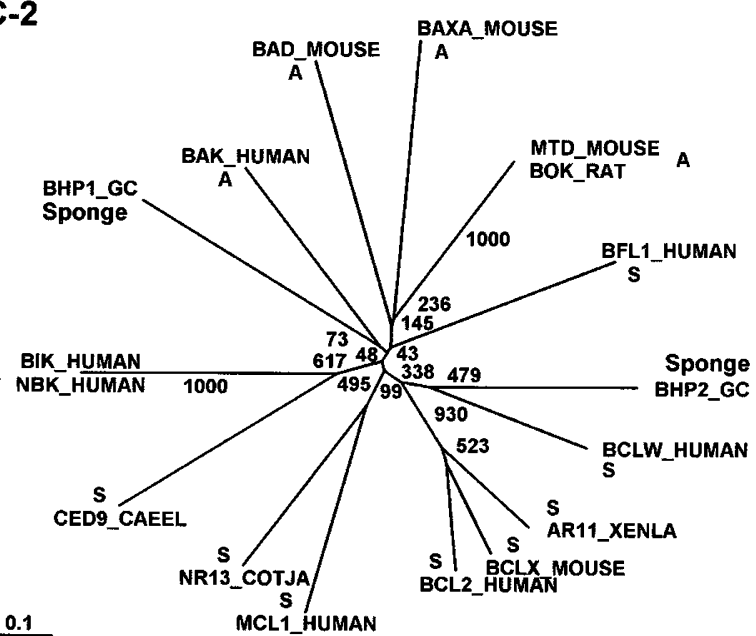

Figure 1 Sponge Bcl-2 homologue proteins and their phylogenetic relationships. (A) Alignments of the two deduced aa sequences of the G. cydonium GCBHP1 (protein BHP1_GC; accession number Y19156), GCBHP2 (BHP2_GC). The alignment was performed using CLUSTAL W program. Similar aa residues are shown in white letters on black background. The $\mathrm{Bcl}-2$ domains, $\mathrm{BH} 1$ and $\mathrm{BH} 2$, as well as the putative transmembrane segment (TM) are indicated. (B) Phylogenetic relationships of the sponge BH1 domains, present in BHP1_GC and BHP2_GC. (B-1) Alignment of the domains in BHP1_GC and BHP2_GC (BHP1_GC, aa segment 144-165; and BHP2_GC, aa 125-145) with the corresponding domains from the pro-survival proteins (marked: $S$ in B-2 and C-2) from higher metazoan phyla, Ced-9 from C. elegans (CED9_CAEEL; P41958, aa 158-180), NR-13 from quail (NR13_COTJA; Q90343, aa 73-95), frog R11 (AR11_XENLA; Q91828, aa 100-121), human MCL-1 (MCL1_HUMAN; Q07820, aa 251-273), human A1-BFL-1 (BFL1_HUMAN; Q16548, aa 76-98), mouse Bcl-xL (BCLX_MOUSE; AAC53459, aa 128-149), human Bcl-2 (BCL2 HUMAN; P10415, aa 135-156) and Bcl-W (BCLW HUMAN; Q92843, aa 84-105) and the following apoptotic proteins (marked: A in B-2 and C-2) the mouse Mtd (MTD_MOUSE; AAC53582, aa 112-133), mouse Bax (BAXA_MOUSE; Q07813, aa 97-119), human Bak (BAK HUMAN; 1096082, aa 116 - 137), mouse Bad (BAD MOUSE; A55671; aa 137-159) and the human activator of apoptosis Hrk (HRK HUMAN; AAC34931, aa 1-20). (B-2) Unrooted tree constructed from sequences listed in B-1 by neighbour-joining as described under Materials and Methods. The numbers at the nodes are an indication of the level of confidence (given in percentage) for the branches as determined by bootstrap analysis [1000 bootstrap replicates]. The scale bar indicates an evolutionary distance of 0.1 aa substitutions per position in the sequence. (C) Phylogenetic relationships of the BH2 domains in the sponge BHP1_GC and BHP2 GC sequences (BHP1 GC, aa 195-216; BHP2 GC, aa 173-193) with the BH2 domains found in the pro-survival proteins Ced-9 from C. elegans (CED9_CAEEL, aa 210-231), NR-13 from quail (NR13_COTJA, aa 123-144), frog R11 (AR11_XENLA, aa 149-170), human Mcl-1 (MCL1_HUMAN, aa 301- 


\section{Resistance of HEK-293 cells against stressors after transfection with GCBHP2}

HEK-293 cells stably transfected with the sponge GCBHP2 have been subjected to two distinct stresses: serum starvation and TBT treatment. The experiments have been performed under conditions described earlier for HEK-293 cells transfected with human Bcl-2 and induced to apoptosis using serum deprivation. ${ }^{34}$

Serum starvation In medium, containing no FCS, the viability of the mock-transfected cells was strongly reduced; after $96 \mathrm{~h}$ only $\approx 10 \%$ of the cells were still viable. However, the number of viable HEK-293 cells transfected with GCBHP2 was significantly enhanced; after an incubation period of $96 \mathrm{~h}$ the per cent of surviving cells was $46 \%$ with respect to the number at the beginning of the experiment. After a period of $72 \mathrm{~h}, 65 \%$ of the GCBHP2-transfected cells survived compared to $15 \%$ in the assays with mock-transfected cells (Figure 5). These values are almost similar to those reported for HEK-293 cells transfected with human $\mathrm{Bcl}-2 ;^{34}$ in this report it was found that $74 \%$ of the cells transfected with the human gene survived, compared with $17 \%$ of mock-transfected cells.

TBT treatment Likewise an increased viability could be determined when GCBHP2-transfected cells were treated with $0.25 \mu \mathrm{M}$ of TBT. As under serum starvation, the concentration of viable cells in transfected cells was markedly increased. After an incubation for $96 \mathrm{~h}$ the per cent of surviving cells was $32 \%$ for GCBHP2-transfected cells, compared to $5 \%$ of the mock-transfected cells. During a period of $72 \mathrm{~h}, 52 \%$ of the GCBHP2-transfected cells were alive compared to $12 \%$ in the assays with mock-transfected cells (data not shown).

In order to demonstrate that the level of GCBHP2expression in HEK-293 cells was not altered after treatment with the stressors, the cell extracts were analyzed for the expression of the sponge gene. The extracts were subjected to Western blot analysis and reacted with the PoAb-BHP2GC antibody. The $26 \mathrm{kDa}$ signal, corresponding to the sponge (recombinant) BHP2_GC protein, was found not to be significantly changed during the $92 \mathrm{~h}$ incubation period in the assays under serum starvation or in cells after TBT treatment (data not shown).

\section{Expression of human $\mathrm{Bcl}-2$ in transfected cells under stress conditions}

In parallel, the expression of the cellular $\mathrm{Bcl}-2$ gene was monitored on protein level by Western blotting. The results revealed that both in non-treated cells (time zero) as well as in BHP2_GC-transfected cells the Bcl-2 protein $(29 \mathrm{kDa})$ is present at almost the same level, irrespectively of the presence of serum in the culture medium (Figure 6).

\section{Effect of the stressors on the activation of caspase-3}

Quantitation of caspase-3 activity in HEK-293 cells was performed by measuring cleavage of the fluorescent peptide AC-DEVD-AMC [Ac-Asp-Glu-Val-Asp-(7-amino-4-methylcoumarin). This peptide mimics the target sequence of the group II effector caspases. ${ }^{35}$ Treatment of mock-transfected HEK293 under serum starvation resulted in a significant increase in caspase activity above control levels within the first $20 \mathrm{~h}$ of incubation. As shown in Figure 6, the increase of caspase activity in BHP2_GC-transfected cells is significantly lower compared to mock-transfected HEK-293 cells. Similar results were observed with BHP2_GC-transfected cells and mocktransfected HEK-293 cells which had been treated with TBT (data not shown). Therefore, we conclude that BHP2_GCtransfected HEK-293 cells are significantly more resistant towards the apoptotic stressors serum starvation and TBT than mock-transfected cells.

\section{Discussion}

One key pathway in the development and homeostasis of Metazoa is the active form of cell death, apoptosis. This form of cell death allows the organism to remove unwanted and/or damaged cells that could cause inflammation. In Metazoa, the apoptotic pathway(s) have been described, until recently, only in phyla evolved from the hypothetical ancestor of the Protostomia and Deuterostomia, the Urbilateria (reviewed $\mathrm{in}^{36,37}$ ). As model systems for Protostomia, the nematode Caenorhabditis elegans and for Deuterostomia the mammalian systems, e.g. Homo sapiens (reviewed in $^{15,36}$ ), have been well described. With the recent description of the presence of pro-apoptotic as well as pro-survival molecules, $^{1,2}$ in sponges, the closest relative to the common ancestral phylum of all Metazoa, the Urmetazoa, ${ }^{38}$ a new avenue to the understanding of basic apoptotic pathways in all Metazoa phyla became possible.

One suitable approach to prove that the sponge molecules are true homologues to the nucleotide sequence-related molecules identified in other Metazoan phyla, is the performance of transfection studies in heterologous cell systems. In the present work the gene from $G$. cydonium encoding the putative pro-survival protein BHP2_GC, GCBHP2 was stably transfected into human embryonic kidney cells HEK-293. The deduced polypeptide of BHP2_GC comprises the two characteristic Bcl-2 protein family domains $\mathrm{BH} 1$ and $\mathrm{BH} 2$. These domains are known to be important for Bcl-2 to form heterodimeric complexes with the family members and to carry out the anti-apoptotic

322), the mouse Bcl-2 sequences Bcl-xL (BCLX_MOUSE, aa 177-198), human Bcl-W (BCLW_HUMAN, aa 133-154) and human Bcl-2 (BCL2_HUMAN, aa 184205) as well as human A1-Bfl-1 (BFL1 HUMAN, aa 129-150), and the following apoptotic proteins mouse Bax (BAXA MOUSE, aa 127-149), mouse Mtd (MTD_MOUSE, aa 161-182), mouse Bad (BAD_MOUSE, aa 172-193), human Bak (BAK_HUMAN, aa 166-186), human apoptosis inducer Bik (BIK_HUMAN; Q13323, aa 118-140), human apoptosis inducer Nbk (NBK_HUMAN; AAC79124, aa 118-140), and rat Bcl-2-related ovarian killer protein Bok (BOK_RAT; AAC61928, aa 118-139). C-1 Alignment and C-2 unrooted tree 


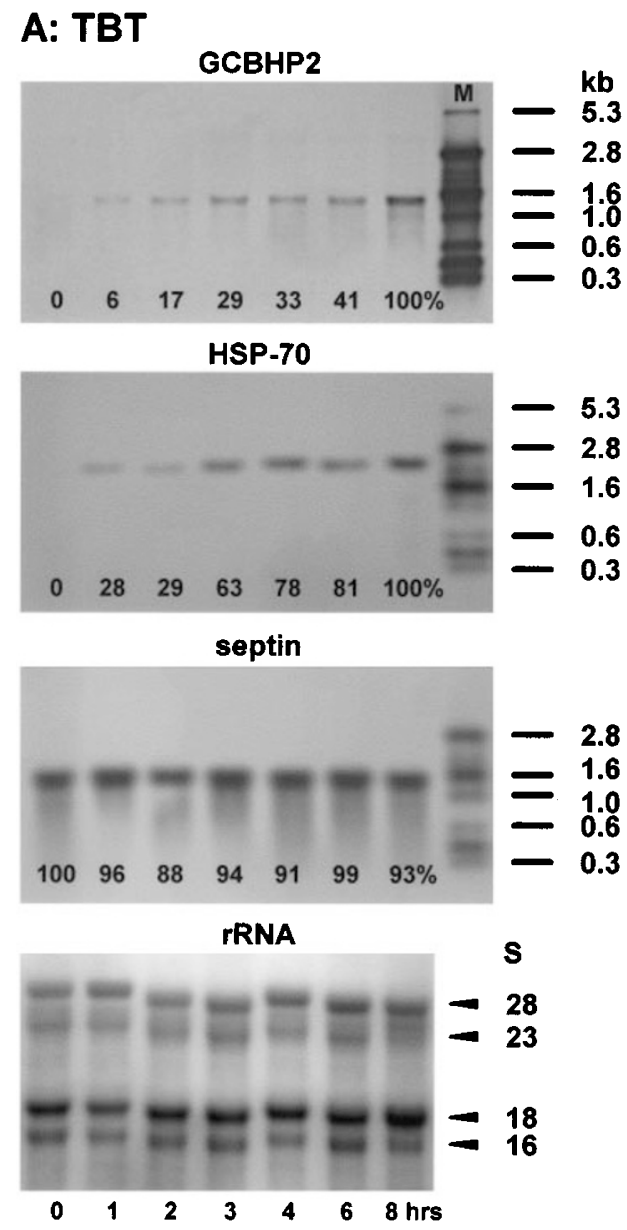

\section{B: Heat shock}
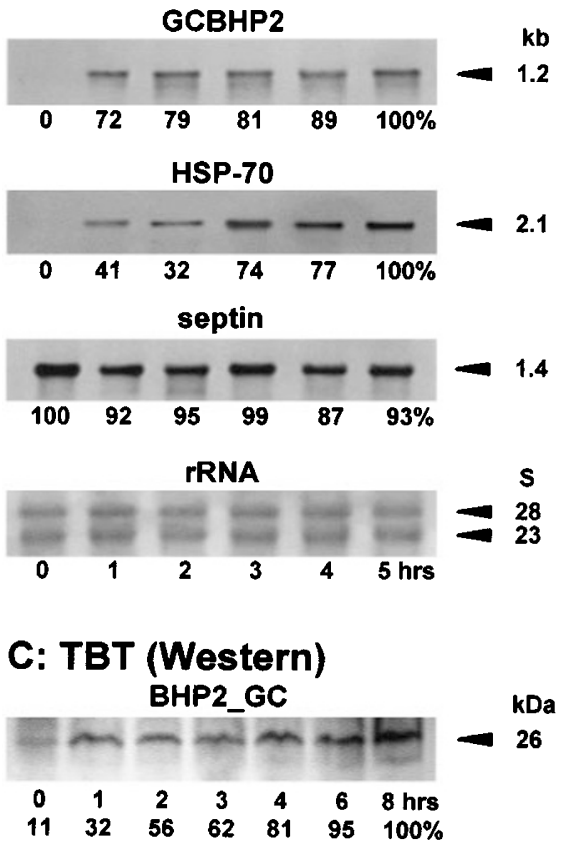

Figure 2 Effect of two stressors on tissue samples from G. cydonium. (A) Effect of TBT on the expression of GCBHP2 (encoding for GCBHP2), GCHSP70 (HSP-70) and GCSEP1 (septin). A concentration of $1 \mu \mathrm{M}$ was function (reviewed in ${ }^{16}$ ). Mutations in $\mathrm{BH} 1$ and $\mathrm{BH} 2$ prevent $\mathrm{Bcl}-2$ from the formation of heterodimers with Bax, a homologue of $\mathrm{Bcl}-2$, resulting in an abrogation of the $\mathrm{Bcl}-2$ mediated cell survival. ${ }^{16}$
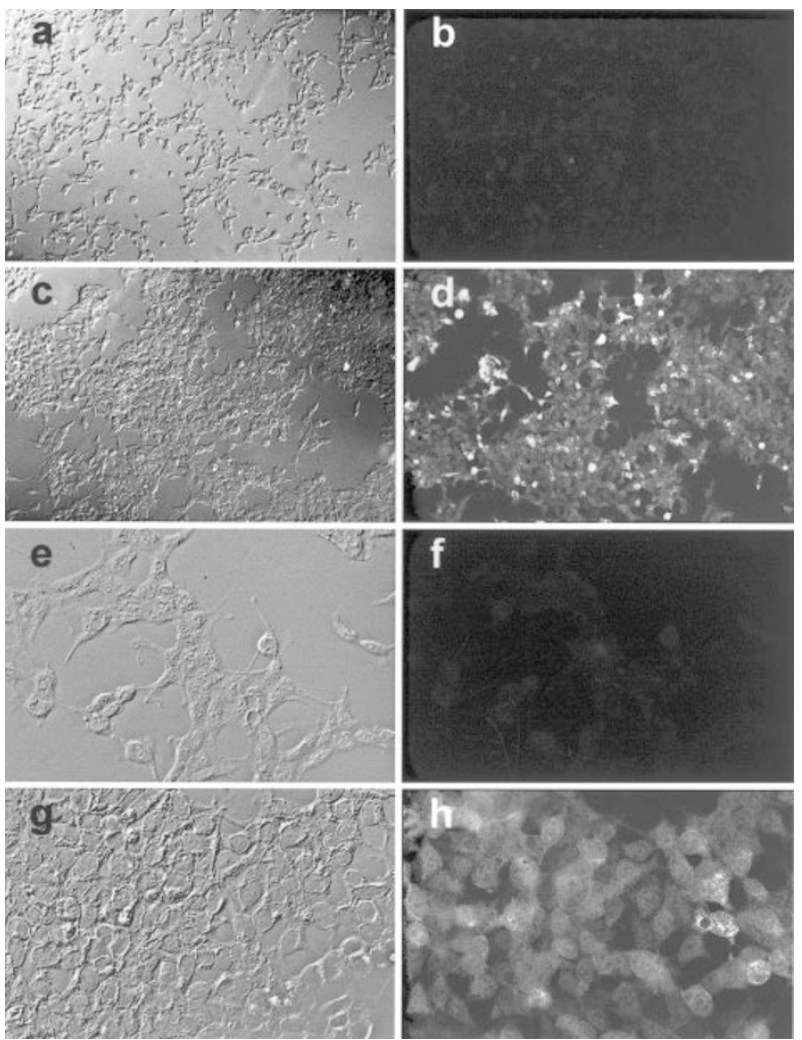

Figure 3 Identification of the expressed G. cydonium GCBHP2 in HEK-293 cells by immunofluorescence studies. Cells were stably transfected using the expression plasmid lacking GCBHP2 (a and $\mathbf{b}$; e and $\mathbf{f}$ ) or with the plasmid containing GCBHP2 as an insert (c and $\mathbf{d} ; \mathbf{g}$ and $\mathbf{h}$ ). After fixation the cells were permeabilized and stained with PoAb-BHP2GC followed by incubation with Cy3-labeled anti-rabbit Ig. Inspection with Nomarsky: a, c, e and $\mathbf{g}$; analysis by fluorescence microscopy: $\mathbf{b}, \mathbf{d}, \mathbf{f}$ and $\mathbf{h}$. Magnification: $\mathbf{a}-\mathbf{d}, \times 25$; and $e-f \times 150$

chosen. Tissue samples were taken after an incubation period of $0-8 \mathrm{~h}$ (as indicated). Then RNA was prepared and subjected to Northern blot analysis. $5 \mu \mathrm{g}$ of RNA per slot were loaded onto the gel. After separation and blot transfer, hybridization was performed as described under Materials and Methods. The signals were visualized applying the chemiluminescence procedure. The intensities of the transcripts for GCBHP2, GCHSP70 and GCSEP1 are correlated with the highest level of expression for the respective gene (this value was set to $100 \%$ ). To assure that the same amount of RNA was loaded, the gel was stained with toluidine blue to visualize the rRNA. M: size markers used. (B) Effect of heat shock on the expression of the sponge genes GCBHP2, GCHSP70 and GCSEP1 in tissue samples. The tissue samples were taken $0-5 \mathrm{~h}$ after heat shock, as described under Materials and Methods. RNA was isolated, blot transferred and probed with GCBHP2, GCHSP70 and GCSEP1. (C) Effect of TBT on BHP2_GC protein expression in G. cydonium tissue. Samples were treated with TBT $(1 \mu \mathrm{M})$ for $0-8 \mathrm{~h}$, protein was extracted and subjected to Western blot analysis. Equal amounts of protein were loaded onto the gel. After separation and blot transfer, the blots were incubated with PoAb-BHP2GC and processed as described under Materials and Methods 

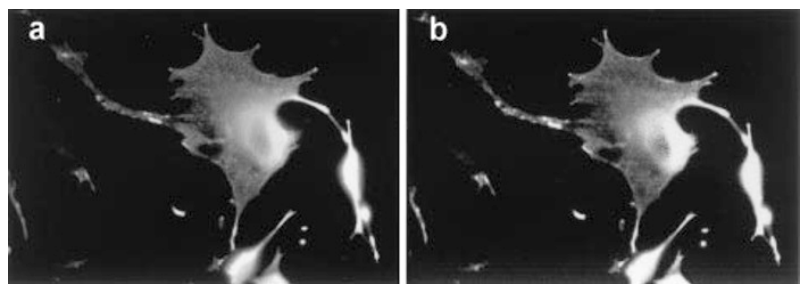

Figure 4 Immunofluorescence analysis of expressed sponge GCBHP2 in mouse NIH-3T3 cells. These cells were stably transfected with GCBHP2 and subsequently stained with the anti-Hexa-His antibody [polyclonal] (a) and with antibody against a mitochondrial protein, p33/gC1qR [monoclonal] (b) HexaHis antigen/antibody complexes were identified with Cy3-conjugated secondary antibody and the $\mathrm{p33/gC1qR}$ antigen/antibody complexes with an FITC-labeled secondary antibody. Magnification: $\times 600$

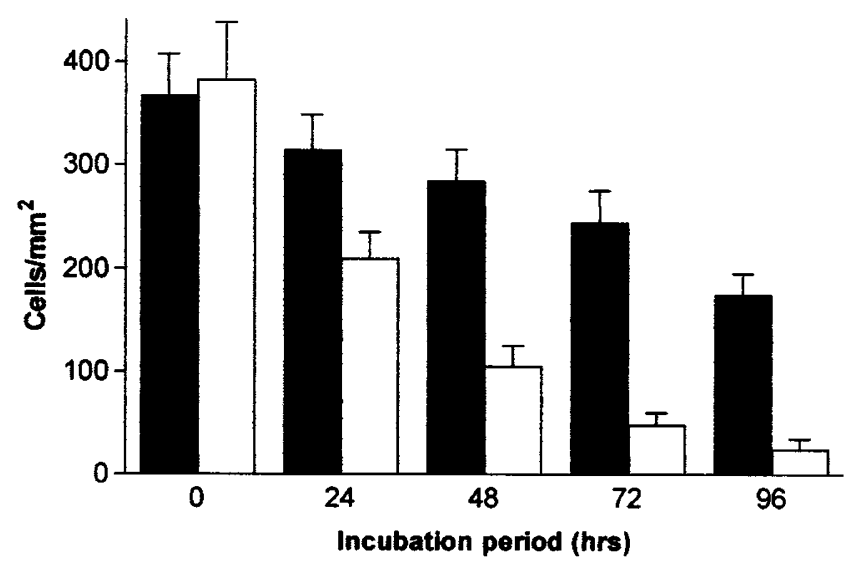

Figure 5 Increase of survival of HEK-293 cells, transfected with GCBHP2. The cells were kept under serum-starved conditions and incubated for $0-96 \mathrm{~h}$ After the indicated periods the concentration of viable cells per square $\mathrm{mm}$ was determined in GCBHP2-transfected cultures (closed bars) and in mocktransfected ones (open bars). Further details are given under Materials and Methods

In the first series of experiments the expression of the sponge Bcl-2-related molecule BHP2_GC in the sponge tissue was studied in response to defined stressors. The capacity of inducers to cause apoptosis depends on the respective species, tissues or cells (reviewed $\mathrm{in}^{39}$ ). Therefore, in the present study the established stimuli for apoptosis in sponges, TBT $^{26}$ and heat shock ${ }^{40}$ have been chosen. With respect to HEK-293 cells serum starvation and TBT, both triggering the cells to apoptosis dosedependently via the caspase pathway, ${ }^{25,30}$ have been selected as inducers.

As a measure of apoptosis the TUNEL assay had previously been used in the sponge system. ${ }^{41}$ Considering the limitations of this assay, functional studies have been applied here. Until now the searches for caspases in sponges have been without success. Therefore, as a molecular marker for viability and proliferation the expression of septin, which is involved in the orientation of the cleavage planes during cell division, ${ }^{28}$ has been chosen. ${ }^{42,43}$ The experiments with tissue from $G$. cydonium revealed that in response to $1 \mu \mathrm{M}$ of TBT and heat shock $\left(1-5 \mathrm{~h}\right.$ at $9^{\circ} \mathrm{C}$ above ambient temperature), the expression
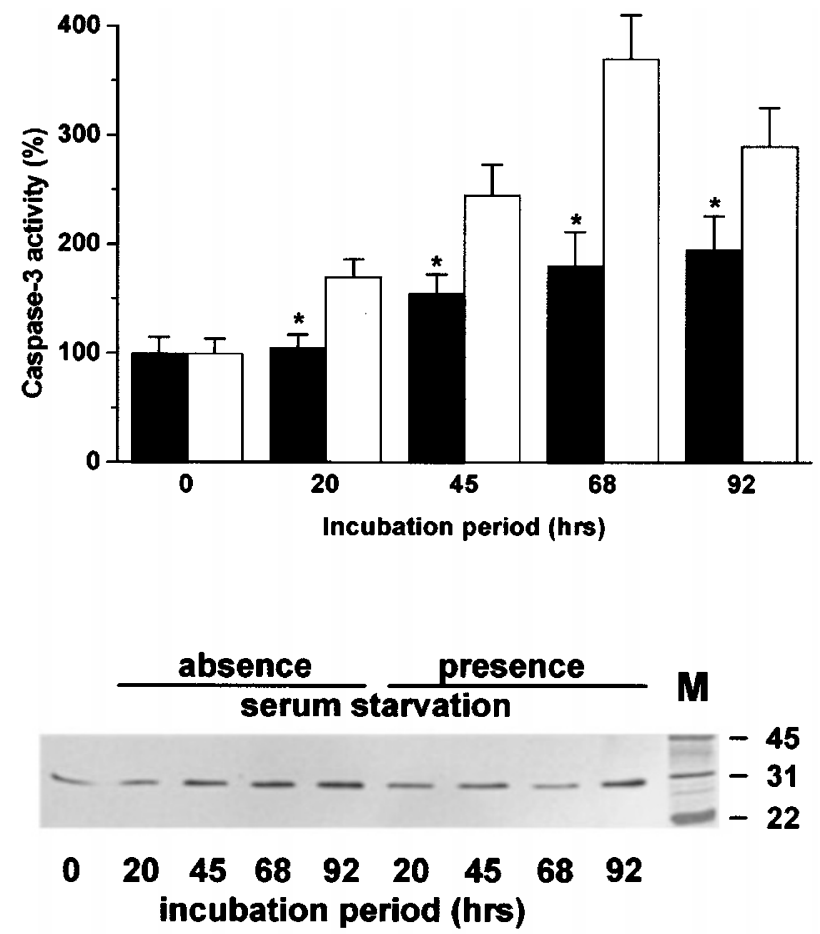

Figure 6 Caspase activation and Bcl-2 expression in HEK-293 cells in the absence or presence of serum. Above Time course of caspase activation in mock-transfected (open bars) and GCBHP2-transfected HEK-293 cells (closed bars). HEK-293 cells were incubated in the absence of FCS for 0 $92 \mathrm{~h}$. Then the activity of caspase- 3 was determined as described under Materials and Methods; the control values were set to $100 \%$. The asterisks indicate the statistical significance $(P<0.005)$ of the difference between the activities measured in the extracts from mock-transfected and those from GCBHP2-transfected HEK-293 cells; $n=20$. Below Expression of $\mathrm{Bcl}-2$ in GCBHP2-transfected HEK-293. As indicated, the cells were incubated for 0$92 \mathrm{~h}$ in the presence or absence of serum as outlined under Materials and Methods. Then total protein was extracted and analyzed for the level of Bcl-2 protein by Western blotting. The positions of marker proteins $(M)$ were given

of $G C B H P 2$ is upregulated with almost the same kinetics like the gene GCHSP70, encoding the sponge heat shock protein-70. Under the conditions chosen, the level of expression for the septin gene remains unchanged. These data show that the sponge $\mathrm{Bcl}-2$ homologue GCBHP2 is, like the mammalian $B c /-2$ gene $\left(\right.$ e.g. ${ }^{44}$ ), inducible; it is selectively upregulated in response to non-toxic apoptotic stimuli. At higher TBT concentrations $(>10 \mu \mathrm{M})$ or more severe heat shock $\left(14^{\circ} \mathrm{C}\right.$ above ambient temperature) the expressions of genes coding for BHP2_GC, HSP-70 and septin decline 26,45 (and unpublished).

Transfection of HEK-293 cells and NIH-3T3 cells with the sponge GCBHP2 was successfully performed as shown both on the transcriptional as well as on the protein level. The GCBHP2 transcripts have been identified by PCR analysis, while the protein expression in the transfected cells was demonstrated by immunofluorescence using antibodies raised against the recombinant BHP2_GC protein. The transfected cells showed a different phenotype, a phenomenon which is known already from previous studies in which HEK-293 cells were transfected with the Kin17 gene. ${ }^{46}$ While the non-transfected cells show the well 
established evenly distributed growth pattern, the transfected cells clumped together. The staining in transfected cells using an antibody against the sponge BHP2_GC protein and a mitochondrial marker protein, $\mathrm{p} 33 / \mathrm{gC} 1 \mathrm{qR}$, gave almost identical patterns. This result suggests that the sponge protein in mammalian cells is co-localized with mitochondria. The association of $\mathrm{Bcl}-2$ with mitochondria in mammalian cells is established (reviewed $\mathrm{in}^{37}$ ).

The expression of the sponge GCBHP2 in HEK-293 cells remained at a high level even after a $92 \mathrm{~h}$ exposure period in medium completely deprived of fetal calf serum. The activation of a caspase, we have selected caspase-3 since this enzyme is involved in the cleavage of $\mathrm{Bcl}_{-\mathrm{XL}}{ }^{47}$ has been measured in serum starved HEK-293 cells. The activity of the enzyme was found to be strongly increased in mock-transfected cells; a considerably lower increase in caspase activity was measured in GCBHP2-transfected cells. In the final series of experiments it was established that cells exposed to medium in the absence of FCS displayed a significantly increased survival rate; as an example, after $72 \mathrm{~h} 65 \%$ of the GCBHP2-transfected cells were found to be still alive compared to $15 \%$ in the assays with mock-transfected cells. This degree of protection against the apoptotic stimulus is almost as high as that seen in HEK-293 cells transfected with the human $\mathrm{Bcl}-2$ gene. $^{34}$ To verify that HEK-293 cells transfected with the sponge gene are also significantly more resistant to other apoptotic stimuli, the cells were treated with TBT. Again, the GCBHP2-transfected cells displayed a much higher survival rate during the $96 \mathrm{~h}$ incubation period compared to the mock-transfected cells.

The data reported here demonstrate that the tools of sponge cultivation ${ }^{48}$ and molecular biology are powerful means to identify components of complex physiological pathways in the phylogenetically oldest metazoan phylum, in sponges. It can now be concluded that these animals comprise also the characteristic metazoan pathway of apoptosis which had been considered until recently to have emerged only in animals evolved from the common ancestor of Protostomia and Deuterostomia. This conclusion is of considerable importance for the understanding of evolution, since yeast, the kingdom which has a common ancestor with Metazoa, ${ }^{49}$ shows the phenomenon of apoptosis without having the metazoan apoptotic/antiapoptotic genes. ${ }^{39}$ Hence it must be concluded (as shown here for BHP2_GC, a member of the Bcl-2 protein family), that key molecules of apoptosis emerged during evolution of the Fungi to the Metazoa. In a subsequent study the function of the sponge pro-apoptotic molecules comprising two death domains ${ }^{2}$ in mammalian cells will be investigated. With respect to the $\mathrm{Bcl}-2$ protein family it can now be stated that this apoptosis regulator family is an autapomorphic character of Metazoa. In addition, this study is also the first to demonstrate that sponge gene(s) can display their function in human cells, again supporting the fact that sponges, as the simplest metazoan animals, share common characteristics with other metazoan taxa. This monophyletic view of animals has been previously proposed based on cDNA sequence data. $^{11}$

\section{Materials and Methods}

\section{Materials}

Restriction endonucleases and other enzymes for recombinant DNA techniques and vectors were obtained as described earlier. ${ }^{50,51}$ In addition, FuGENE 6 reagent, PCR-DIG (digoxigenin)-ProbeSynthesis Kit, anti-DIG AP Fab fragments and CDP [disodium 2-chloro-5-(4-methoxyspiro\{1,2-dioxetane-3,2' -(5'-chloro)-tricyclo [3.3.1.1. ${ }^{3,7}$ ]decan\}-4-yl)phenyl phosphate] from Roche Diagnostics (Mannheim; Germany); RPMI-1640 and OptiMEM from Life Technologies (Karlsruhe; Germany); geneticine G418 from Invitrogen (Groningen; The Netherlands); tributyltin and labelled anti-rabbit Ig from Sigma (Deisenhofen; Germany); AC-DEVD-AMC from Peptide Institute (Osaka; Japan); monoclonal anti-Bcl-2 [human] antibodies (mouse) from Santa Cruz (Santa Cruz, Cal; USA); anti-mouse (Су3 labeled) and anti-rabbit (FITC-labeled) from Dianova (Hamburg; Germany); the mouse anti-Hexa-histidine monoclonal antibody (McAb-anti-His) from Invitrogen (Groningen; The Netherlands). The mammalian cell line was purchased from the American Type Culture Collection (Manassas, VA; USA). The antibody raised against the mitochondrial marker protein $\mathrm{p} 33 / \mathrm{gC} 1 \mathrm{qR}$ was a gift of Drs MüllerEsterl and Dedio. ${ }^{52}$

\section{Sponges}

Specimens of the marine sponge Geodia cydonium (Porifera, Demospongiae, Geodiidae) were collected in the Northern Adriatic near Rovinj (Croatia), and then kept in aquaria in Mainz (Germany) at a temperature of $17^{\circ} \mathrm{C}$.

\section{Exposure of tissue cubes from G. cydonium to selected stressors}

Tissue samples, cubes of $\approx 0.05 \mathrm{~g}$ of $\mathrm{G}$. cydonium remained either untreated in $10 \mathrm{I}$ aquaria at $17^{\circ} \mathrm{C}$ (ambient temperature) under continuous aeration or were exposed to defined stress conditions. The water was changed once daily. For the heat shock experiments the cubes were treated for $1-5 \mathrm{~h}$ at $26^{\circ} \mathrm{C}$. Exposure to tributyltin (TBT) was performed at a concentration of $1 \mu \mathrm{M}$ for $1-8 \mathrm{~h}$. TBT was dissolved in ethanol (final concentration in the cultures $0.01 \%$ ); the control samples were supplemented without the compound but in the presence of the solvent. For the experiments aliquots of the respective sponge samples were taken and immediately frozen in liquid nitrogen and stored at $-80^{\circ} \mathrm{C}$

\section{Cloning of the putative sponge pro-survival cDNA encoding BHP2_GC}

The complete sponge cDNA GCBHP2, encoding the putative $\mathrm{Bcl}-2$ homologous proteins (BHP2_GC), was cloned by screening the cDNA library from $G$. cydonium ${ }^{53}$ using the GCBHP1 (accession number Y $19156^{1}$ ) as a probe. Screening of the library was performed under low stringency hybridization as described before. ${ }^{50}$ Positive clones were detected with an alkaline phosphatase conjugated antidigoxygenin antibody using BCIP/NBT as substrate. ${ }^{54}$ All cDNAs have been obtained at least from two different cDNA libraries resulting in at least three independent clones each. DNA sequencing was performed with an automatic DNA sequenator [Li-Cor 4000S]

\section{Cloning of the putative sponge septin}

The sponge cDNA, encoding the septin-like molecule, termed GCSEP1, was isolated from the G. cydonium cDNA library by 
polymerase chain reaction (PCR). The degenerate reverse primer, directed against the conserved aa segments found in the $P$ loop motif of the Drosophila melanogaster pnut sequence (accession number U08103; ${ }^{55}$ aa $_{148}$ to $\mathrm{aa}_{157}$ ) $5^{\prime}$-TTT/CICCIAGICCICAT/ CTCICCIACIACCAT-3', was used in conjunction with the $5^{\prime}$-end vector-specific primer. Further data will be given elsewhere. The clone was termed GCSEP1.

\section{Sequence comparisons}

The sequences were analyzed using computer programs BLAST ${ }^{56}$ and FASTA. ${ }^{57}$ Multiple alignments were performed with CLUSTAL W Ver. 1.6. ${ }^{58}$ Phylogenetic trees were constructed on the basis of aa sequence alignments by neighbour-joining, as implemented in the 'Neighbor' program from the PHYLIP package. ${ }^{59}$ The distance matrices were calculated using the Dayhoff PAM matrix model as described. ${ }^{60}$ The degree of support for internal branches was further assessed by bootstrapping. ${ }^{59}$ The graphic presentations were prepared with GeneDoc. ${ }^{61}$ The hydropathy values were calculated according to Kyte and Doolittle. ${ }^{62}$

\section{Cell transfection}

HEK-293 The sponge GCBHP2 cDNA was transfected into the human embryonal kidney cells HEK-293 (ATCC CRL 1573). These cells were grown as monolayer in a humidified $5 \% \mathrm{CO}_{2}$ atmosphere at $37^{\circ} \mathrm{C}$ in RPMI- 1640 medium supplemented with $10 \%$ fetal calf serum (v/v; FCS).

A fragment of $771 \mathrm{bp}$ (inclusive the His-tag) from GCBHP2, comprising the complete deduced open reading frame (ORF) was obtained by PCR from $\mathrm{nt}_{-23}$ to $\mathrm{nt}_{-42}$ (forward primer: 5'GGTACCTCACGACGGTCGGCGTATTA-3'; the Kpnl site is underlined), located upstream from the start ATG site, to $\mathrm{nt}_{676}$ to $\mathrm{nt}_{696}$ (reverse primer: 5'-TCTAGATCAGTGATGGTGATGGTGATGTTGTCTCATTCCAAGAGCCAG-3'; the Xbal site is underlined and the six histidine codons are in bold type, TCA is the stop codon). After digestion with $K p n l$ and $X b a l$ the fragment was subcloned into the Kpnl and Xbal sites of the plasmid pcDNA3 (Invitrogen). Cells were transfected using the FuGENE 6 reagent following the procedure described by Mansour et al. ${ }^{63}$ using the pcDNA3 containing the GCBHP2 in transcriptional orientation. As a control, mock-transfection was performed with the $p C D N A 3$ without the GCBHP2 insert.

Cells having reached $50-60 \%$ confluency were transfected with $2.8 \mu \mathrm{g} / \mathrm{ml}$ of pcDNA3-GCBHP2 or pcDNA3 without insert. Immediately prior transfection cells were transferred into OptiMEM, supplemented with $10 \%$ FCS. After $24 \mathrm{~h}$ of incubation of the cells with DNA/FuGENE 6 the transfection medium was changed back to the medium routinely used. To select for stably transfected cells, which had acquired neomycin resistance, G418 $(500 \mu \mathrm{g} / \mathrm{ml})$ was added to the culture medium after an additional $24-48 \mathrm{~h}$ incubation period. After selection with G418 in 96-well plates, cloned tranfectants were maintained in RPMI 1640, containing 10\% FCS. For microscopical inspection the cells were plated onto cover slides. Expression of GCBHP2 was confirmed by Northern blotting, Western blotting and by immunocytochemistry.

For the analysis of the expression of GCBHP2 in HEK-293 cells the method of reverse transcription-PCR ${ }^{64}$ was applied. RNA was extracted $^{64}$ and the sponge GCBHP2 transcripts were identified using the primers (forward primer: $\mathrm{nt}_{-10}$ to $\mathrm{nt}_{11}$; reverse primer: $\mathrm{nt}_{560}$ to $\mathrm{nt}_{580}$ ). As a control, the level of expression of the glyceraldehyde-3phosphate dehydrogenase (GAPDH) was determined. Primers (forward primer: 5'-AATGCCTCCTGCACCACCAA-3' directed against $\mathrm{nt}_{445}$ to $\mathrm{nt}_{464}$; the reverse primer: $5^{\prime}$-GTCGTTGAGGGCAATGCCAGC-3' against $\mathrm{nt}_{895}$ to $\mathrm{nt}_{915}$ of the human GAPDH (accession number NM 002046) were used to identify the transcripts of GAPDH in mock-transfected and GCBHP2-transfected HEK-293 cells. The PCR was carried out as follows: denaturation at $95^{\circ} \mathrm{C}$ ( $\left.3 \mathrm{~min}\right), 35$ amplification cycles $\left(95^{\circ} \mathrm{C}, 30 \mathrm{~s} ; 58^{\circ} \mathrm{C} 45 \mathrm{~s}, 72^{\circ} \mathrm{C} 1.5 \mathrm{~min}\right)$ and final extension $\left(72^{\circ} \mathrm{C}, 10 \mathrm{~min}\right)$. The PCR products were size separated on an agarose gel and stained with ethidium bromide.

NIH-3T3 NIH-3T3 (ATCC CRL 1658) cells were transfected with pcDNA3-GCBHP2 as described above, with the exception that $250 \mu \mathrm{g} / \mathrm{ml}$ of G418 were used for selection. These cells were used for additional immunofluorescence studies to determine the intracellular distribution of the sponge protein.

\section{Treatment of HEK-293 cells with two stressors}

Stably transfected or mock-transfected HEK-293 cells were treated in two ways to induce apoptosis. (1) Serum starvation: The cells were cultured in RPMI 1640 medium in the absence of FCS. After treatment for $0-96 \mathrm{~h}$ cell survival was measured. For the determination of viability the trypan blue-exclusion assay has been applied. Under these conditions the viability in the mocktransfected cells was determined to be $\approx 10 \%$ after a $96 \mathrm{~h}$ incubation period. (2) TBT treatment: The cells were exposed to $0.25 \mu \mathrm{M}$ of TBT for 0 to $96 \mathrm{~h}$. Subsequently, cell viability was determined. After $96 \mathrm{~h}$ the viability in the TBT-treated cultures was $\approx 5 \%$.

\section{Northern blot analysis}

RNA was extracted from liquid-nitrogen pulverized sponge tissue as described. ${ }^{65,66}$ RNA (total) samples $(5 \mu \mathrm{g})$ were electrophoresed in a formaldehyde $/ 1 \%$ agarose gel and blotted onto Hybond $\mathrm{N}^{+}$membrane following the manufacturer's instructions (Amersham; Little Chalfont, Buckinghamshire; UK). Hybridization was performed with the $586 \mathrm{nt}$ long GCBHP2 fragment (spanning $\mathrm{nt}_{83}$ to $\mathrm{nt}_{668}$ of the ORF) in High$\mathrm{NaDodSO}_{4}$ hybridization Buffer $\left(7 \% \mathrm{NaDodSO}_{4}, 50 \%\right.$ formamide, $5 \times \mathrm{SSC}, 0.1 \%$ Na-laurylsulfate, $50 \mathrm{mM} \mathrm{Na}_{3} \mathrm{PO}_{4}[\mathrm{pH} 7.0]$ and $2 \%$ of blocking reagent [Roche]) at $42^{\circ} \mathrm{C}$. The probe had been labeled using the PCR-DIG-Probe Synthesis kit (Roche) according to the 'Instruction Manual' (Roche), applying the primers corresponding to $\mathrm{nt}_{83}$ to $\mathrm{nt}_{103}$ and $\mathrm{nt}_{648}$ to $\mathrm{nt}_{668}$. In parallel, the blots were hybridized with the $762 \mathrm{bp}$ long heat shock protein-70 probe from G. cydonium $\left(\mathrm{nt}_{303}\right.$ to $\mathrm{nt}_{1064}$ GCHSP70; accession number $\times 94985^{40}$ ), or the 799 bp long $G$. cydonium septin probe $\left(\mathrm{nt}_{-3}\right.$ to $\mathrm{nt}_{796}$ GCSEP1 cloned in the present study). The signals of the Northern blot were visualized by the chemiluminescence procedure ${ }^{67} \mathrm{CDP}$-Star was used as substrate. To quantitate the signals of the Northern blots the screen was scanned with the GS-525 Molecular Imager (Bio-Rad). The relative values for the expressions are given. To document that the same amount of RNA was loaded onto the gels the total RNA was stained with toluidine blue; using this technique both the eukaryotic [28S and $18 \mathrm{~S} \mathrm{rRNA}$ ] as well as the prokaryotic rRNA species [23S and $16 \mathrm{~S}$ ] became visible. It is known that the majority of demosponges, including G. cydonium, harbors bacteria. ${ }^{68}$

\section{GCBHP2 cDNA expression and antibody preparation}

A fragment of GCBHP2 ranging from $\mathrm{nt}_{83}$ to $\mathrm{nt}_{659}$ has been used for the expression of the protein; a forward primer, $5^{\prime}$-GGATCCT- 
GATGGAGATGGAGGAGCTCTACAGAA- ${ }^{\prime}$, comprising $\mathrm{nt}_{83}$ to $\mathrm{nt}_{103}$ of the coding region (the $B a m \mathrm{HI}$ site is underlined); and a reverse primer, 5'-GTCGACATGACACCAATACCGGCTACT-3'; nt ${ }_{639}$ to $\mathrm{nt}_{659}$ (the Sa/l site is underlined) was chosen for the PCR. This cDNA was used for expression in Escherichia coli as described. ${ }^{53,69}$ The cDNA was inserted into the bacterial oligohistidine expression vector $\mathrm{PQE}-32$ (Quiagen). E. coli (XL1-blue) were transformed with this plasmid and expression of fusion protein was induced with isopropyl 1-thio- $\beta$-Dgalactopyranoside (IPTG). Bacteria were extracted with phosphate buffered saline (PBS)/urea and the suspension was centrifuged; the supernatant was collected 'bacterial crude extract'. The purification of the recombinant oligohistidine-BHP2GC fusion proteins, termed rBHP2GC, was performed by metal-chelate affinity chromatography using Ni-NTA-agarose resin (Qiagen) according to Hochuli et al. ${ }^{70}$ as well as by the 'Instruction of Manufacturer'. The purity of the material was checked by $15 \%$ polyacrylamide gels containing $0.1 \% \mathrm{NaDodSO}_{4}$ [PAGE] according to Laemmli. ${ }^{71}$

Polyclonal antibodies against $\mathrm{rBHP} 2 \mathrm{GC}$ were raised in rabbits as described. ${ }^{72}$ Purified rBHP2GC $(3 \times 10 \mu \mathrm{g}$ of protein) was injected; after 15-weeks serum was collected and the antibodies were prepared; ${ }^{73}$ they are termed PoAb-BHP2GC. In control experiments $100 \mu \mathrm{l}$ of the PoAb-BHP2GC were adsorbed to $50 \mu \mathrm{g}$ of $\mathrm{rBHP} 2 \mathrm{GC}$ $\left(30 \mathrm{~min} ; 4^{\circ} \mathrm{C}\right)$ prior to its use.

\section{Western blot analysis}

HEK-293 cells or sponge tissue were lysed in $50 \mathrm{mM}$ Tris- $\mathrm{HCl}(\mathrm{pH} 7.5$; $150 \mathrm{mM} \mathrm{NaCl}, 1 \%$ Triton, aprotinin [0.10 U/ml), $20 \mathrm{mM}$ leupeptin and $1 \mathrm{mM}$ phenylmethylsulfonyl fluoride). Lysates were separated by $\mathrm{NaDodSO}_{4}-\mathrm{PAGE}(15 \% \mathrm{gel})$ and transferred to a nitrocellulose membrane. ${ }^{74}$ After blocking with Blocking Reagent (Roche) for $1 \mathrm{~h}$, the membrane was incubated with the primary (PoAb-BHP2GC [1:10 000 dilution]), then with the secondary antibody (anti-rabbit Ig [1: 10000 dilution]) for $1 \mathrm{~h}$ each, and finally developed with enhanced chemiluminesence (Amersham).

\section{Immunofluorescence analysis}

Transfected cells were washed twice in PBS, fixed and permeabilized with methanol/0.02\% (w/v) EGTA for $10 \mathrm{~min}$. After a further washing procedure (three times) the cells were incubated with PoAb-BHP2GC (1: 1000 dilution in Blocking Reagent) for $60 \mathrm{~min}$ at $37^{\circ} \mathrm{C}^{74}$ The cells were again washed three times with PBS and incubated with Сy3conjugated goat anti-rabbit Ig (1:100 dilution in Blocking Reagent) for $30 \mathrm{~min} 37^{\circ} \mathrm{C}$. The cells were embedded into PBS/glycerol $(1: 1 ; \mathrm{v} / \mathrm{v})$ and inspected with an Olympus AHBT3 microscope.

In a parallel series of experiments, $\mathrm{NIH}-3 \mathrm{~T} 3$ cells transfected with pcDNA3-GCBHP2, were stained with an anti-Hexa-His antibody (1:200 dilution) and, in addition, with an antibody raised against the mitochondrial marker protein anti-p33/gC1qR (polyclonal antibodies [rabbits]; $1: 20$ dilution). ${ }^{52}$ The antigen/antibody immunocomplexes were detected either with anti-mouse (Cy3 labeled [identification of the His-labeled BHP2GC]) or with anti-rabbit (FITC labeled [anti-p33/ gC1qR]) antibodies.

\section{Caspase-3 assay}

For the testing of caspase-3 activity HEK-293 cells were lysed in $10 \mathrm{mM}$ HEPES-KOH [pH 7.4], $2 \mathrm{mM}$ ethylenediaminetetra-acetic acid, $5 \mathrm{mM}$ dithiothreitol (DTT), $1 \mathrm{mM}$ phenylmethylsulfonyl fluoride (PMSF) and $0.1 \%$ CHAPS. Subsequently, $50 \mu$ aliquots were added to the $50 \mu \mathrm{l}$ caspase assay which contained the following components (final concentrations): $20 \mathrm{mM}$ HEPES-KOH [pH 7.4], 10\% glycerol, $0.5 \mathrm{mM}$ PMSF, $2 \mathrm{mM}$ DTT and $20 \mu \mathrm{M}$ of the caspase- 3 substrate AcDEVD-AMC. Substrate cleavage to release free AMC (excitation at $355 \mathrm{~nm}$; emission at $460 \mathrm{~nm}$ ) was monitored at $37^{\circ} \mathrm{C}$ (after $3 \mathrm{~h}$ ). Fluorescence units measured were normalized with respect to protein concentration. The values measured for the non-treated cells, either mock-transfected or GCBHP2 transfected, at the indicated time were set to $100 \%$. In parallel, Western blot experiments were performed with the same extracts; total tissue extracts ( $10 \mu \mathrm{g} / \mathrm{lane})$ were subjected to electrophoresis in $15 \%$ polyacrylamide gels containing $0.1 \%$ $\mathrm{NaDodSO}_{4}$ as described above. After electrophoresis the proteins were transferred to a nitrocellulose membrane and incubated with antiBcl-2 antibodies [1:2500 dilution]) and then with the secondary antibody (anti-mouse Ig [1:10 000 dilution]).

\section{Further analytical procedure}

For protein determination the Fluoram method was used the standard was bovine serum albumin. ${ }^{75}$

\section{GenBank information}

The sequence reported here is deposited in the EMBL/GenBank data base (Accession no. AJ293508 for the Geodia cydonium Bcl-2 homologous protein BHP2 and AJ293509 for the G. cydonium septin).

\section{Acknowledgements}

This work was supported by grants from the Deutsche Forschungsgemeinschaft (Mü 348/14-) and the International Human Frontier Science Program (RG-333/96-M).

\section{References}

1. Wiens M, Krasko A, Müller Cl and Müller WEG (2000) Molecular evolution of apoptotic pathways: cloning of key domains from sponges (Bcl-2 homology domains and death domains) and their phylogenetic relationships. J. Mol. Evol. 50: $520-531$

2. Wiens M, Krasko A, Müller IM and Müller WEG (2000) Increased expression of the potential proapoptotic molecule DD2 and increased synthesis of leukotriene $\mathrm{B}_{4}$ during allograft rejection in a marine sponge. Cell Death Differ. 7: 461-469

3. Vaux DL, Haecker G and Strasser A (1994) An evolutionary perspective on apoptosis. Cell 76: $777-779$

4. Lockshin RA and Williams CM (1964) Programmed cell death. II: Endocrine potentiation of the breakdown of the intersegmental muscles of silkmoths. J. Insect Physiol. 10: 643-649

5. Kerr JFR, Wyllie AH and Currie AH (1972) Apoptotis, a basic biological phenomenon with wider implications in tissue kinetics. Br. J. Cancer 26: 239 245

6. Lincz L (1998) Deciphering the apoptotic pathway: all roads lead to death. Immunol. Cell. Biol. 76: 1-19

7. Müller WEG (2001) How was Metazoan threshold crossed? The hypothetical Urmetazoa. Comp. Biochem. Physiol. (A); in press.

8. Müller WEG (1997) Origin of metazoan adhesion molecules and adhesion receptors as deduced from their cDNA analyses from the marine sponge Geodia cydonium. Cell Tissue Res. 289: 383-395

9. Müller WEG (1998) Origin of Metazoa: sponges as living fossils. Naturwissenschaften 85: 11-25

10. Müller WEG, Blumbach B and Müller IM (1999) Evolution of the innate and adaptive immune systems: relationships between potential immune molecules in the lowest metazoan phylum [Porifera] and those in vertebrates. Transplantation 68: $1215-1227$ 
11. Müller WEG (1995) Molecular phylogeny of metazoa [animals]: monophyletic origin. Naturwissenschaften 82: $321-329$

12. Williams GT and Smith CA (1993) Molecular regulation of apoptosis: genetic controls on cell death. Cell 74: 777-779

13. Oltvai ZN, Milliman CL and Korsmeyer SJ (1993) Bcl-2 heterodimerizes in vivo with a conserved homolog, Bax, that accelerates programmed cell death. Cell 74: 609-619

14. Cleary ML and Sklar J (1985) Nucleotide sequence of a t $(14 ; 18)$ chromosomal breakpoint in follicular lymphoma and demonstration of a breakpoint-cluster region near a transcriptionally active locus on chromosome 18. Proc. Natl. Acad. Sci. USA 82: $7439-7443$

15. Adams JM and Cory S (1998) The Bcl-2 protein family: arbiters of cell survival. Science 281: $1322-1326$

16. Yin XM, Oltvai ZN and Korsmeyer SJ (1994) BH1 and BH2 domains of Bcl-2 are required for inhibition of apoptosis and heterodimerization with Bax. Nature 369: $321-323$

17. Muchmore SW, Sattler M, Liang H, Meadows RP, Harlan JE, Yoon HS, Nettesheim D, Chang BS, Thompson CB, Wong SL, Ng SC and Fesik SW (1996) $\mathrm{X}$-ray and NMR structure of human $\mathrm{Bcl}-\mathrm{xL}$, an inhibitor of programmed cell death. Nature 381: $335-341$

18. Sato T, Irie S, Krajewski S and Reed JC (1994) Cloning and sequencing of a cDNA encoding the rat Bcl-2 protein. Gene 140: 291-292

19. Otter I, Conus S, Ravn U, Rager M, Olivier R, Monney L, Fabbro D and Borner C (1998) The binding properties and biological activities of bcl-2 and bax in cells exposed to apoptotic stimuli. J. Biol. Chem. 273: 6110-6120

20. Chittenden T, Flemington $C$, Houghton AB, Ebb RG, Gallo GJ, Elangovan B Chinnadurai G and Lutz RJ (1995) A conserved domain in Bak, distinct from BH1 and $\mathrm{BH} 2$, mediates cell death and protein binding function. EMBO J. 14:55895596

21. Cheng EH, Levine B, Boise LH, Thompson CB and Hardwick JM (1996) Baxindependent inhibition of apoptosis by Bcl-XL. Nature 379: $554-556$

22. Lucas JM, Bryans M, Lo K, Wilkie NM, Freshney M, Thornton D and Lang JC (1994) The FGF-4 promoter is required for transformation and is active in both embryonal and somatic cells. Oncol. Res. 6: 139-149

23. Lin EY, Orlofsky A, Berger MS and Prystowsky MB (1993) Characterization of $A 1$, a novel hemopoietic-specific early-response gene with sequences similarity to Bcl-2. J. Immunol. 151: 1979-1988

24. Neilan JG, Lu Z, Afonso CL, Kutish GF, Sussman MD and Rock DL (1993) An African swine fever virus gene with similarity to the proto-oncogene $\mathrm{Bcl}-2$ and the Epstein-Barr virus gene BHF1. J. Virol. 67: 4391-4394

25. Stridh H, Orrenius S and Hampton MB (1999) Caspase involvement in the induction of apoptosis by the environmental toxic tributyltin and triphenyltin. Toxicol. Appl. Pharmacol. 156: 141-146

26. Batel R, Bihari N, Rinkevich B, Dapper J, Schäcke H, Schröder HC and Müller WEG (1993) Modulation of organotin-induced apoptosis by the water pollutant methyl mercury in a human lymphoblastoid tumor cell line and a marine sponge. Marine Ecol. Prog. Ser. 93: 245-251

27. Reader S, Moutardier V and Denizeau F (1999) Tribultyltin triggers apoptosis in trout hepatocytes: the role of $\mathrm{Ca}^{2+}$, protein kinase $\mathrm{C}$ and proteases. Biochim. Biophys. Acta 1448: 473-485

28. Chant J(1996) Septin scaffolds and cleavage planes in Saccharomyces. Cell 84 $187-190$

29. Gibson S, Tu S, Oyer R, Anderson SM and Johnson GL (1999) Epidermal growth factor protects epithelial cells against Fas-induced apoptosis. Requirement for AKT activation. J. Biol. Chem. 274: 17612-17618

30. Gibson RM (1999) Caspase activation is downstream of commitment of apoptosis of Ntera-2 neuronal cells. Exp. Cell Res. 252: 203-212

31. PC/GENE (1995) Data Banks CD-ROM; Release 14.0. IntelliGenetics, Inc. Mountain View, CA

32. Yang E and Korsmeyer SJ (1996) Molecular thanatopsis: a discourse on the BCL2 family and cell death. Blood 88: 386-401

33. Huang ACS, Adams JM and Cory S (1998) The conserved N-terminal BH4 domain of $\mathrm{Bcl}-2$ homologues is essential for inhibition of apoptosis and interaction with CED-4. EMBO J. 17: 1029-1039

34. Turner PR, Mefford S, Christakos S and Nissenson RA (2000) Apoptosis mediated by activation of the $G$ protein-coupled receptor for parathyroid hormone (PTH)/PTH-related protein (PTHrP). Mol. Endocrin. 14: 241-254
35. Nicholson DW, Ambereen A, Thornberry NA, Vaillancourt JP, Ding CK, Gallant M, Gareau Y, Griffin PR, Labelle M, Lazebnik YA, Munday NA, Raju SM, Smulson ME, Yamin TT, Yu VL and Miller DK (1995) Identification and inhibition of the ICE/ CED-3 protease necessary for mammalian apoptosis. Nature 376: 37-43

36. DeRobertis EM and Sakai Y (1996) A common plan for dorsoventral patterning in Bilateria. Nature 380: $37-40$

37. Bruckheimer EM, Cho SH, Sarkiss M, Herrmann J and McDonnell TJ (1998) The $\mathrm{Bcl}-2$ gene family and apoptosis. In: Apoptosis, Scheper T (ed) Advances in Biochemical Engineering/Biotechnology Vol. 62. pp. 75-105

38. Müller WEG and Müller I (2000) How was the Protozoa - Metazoa threshold crossed: The Urmetazoa. Comp. Biochem. Physiol. Part B 126: S69

39. Fröhlich KU and Madeo F (2000) Apoptosis in yeast - a monocellular organism exhibits altruistic behaviour. FEBS Lett. 473: 6-9

40. Koziol C, Wagner-Hülsmann C, Cetkovic H, Gamulin V, Kruse M, Pancer Z, Schäcke $H$ and Müller WEG (1996) Cloning of the heat-inducible biomarker, the cDNA encoding the 70-kDa heat shock protein, from the marine sponge Geodia cydonium: Response to natural stressors. Marine Ecol. Progr. Ser. 136: 153 161

41. Krasko A, SchröderHC, Perovic S, Steffen R, Kruse M, ReichertW, Müller IMand Müller WEG (1999) Ethylene modulates gene expression in cells of the marine sponge Suberites domuncula and reduces the degree of apoptosis. J. Biol. Chem. 274: $31524-31530$

42. Barral Y, Parra M, Bidlingmaier S and Snyder M (1999) Nim1-related kinases coordinate cell cycle progression with the organization of the peripheral cytoskeleton in yeast. Genes Dev. 13: 176-187

43. Xiong JW, Leahy A and Stuhlmann H (1999) Retroviral promoter-trap insertion into a novel mammalian septin gene expressed during mouse neuronal development. Mech. Dev. 86: 183-191

44. Suschek CV, Krischel V, Bruch-Gerharz D, Berendji D, Krutmann J, Kroncke KD and Kolb-Bachofen V (1999) Nitric oxide fully protects against UVA-induced apoptosis in tight correlation with Bcl-2 up-regulation. J. Biol. Chem. 274:6130 6137

45. Koziol C, Batel R, Arinc E, Schröder HC and Müller WEG (1997) Expression of the potential biomarker heat shock protein 70 and its regulator, the metazoan DnaJ homolog, by temperature stress in the sponge Geodia cydonium. Marine Ecol. Progr. Ser. 154: 261-268

46. BiardDS, Kannouche P, Lannuzel-Drogou C,Mauffrey P, Apiou F and Angulo JF (1999) Ectopic expression of (Mm)Kin17 protein inhibits cell proliferation of human tumor-derived cells. Exp. Cell Res. 250: 499-509

47. Clem RJ and ten others (1998) Modulation of cell death by $\mathrm{Bcl}_{\mathrm{XL}}$ through caspase interaction. Proc. Natl. Acad. Sci. USA 95: 554-559

48. Müller WEG, Wiens M, Batel R, Steffen R, Borojevic R and Custodio MR (1999) Establishment of a primary cell culture from a sponge: primmorphs from Suberites domuncula. Marine Ecol. Progr. Ser. 178: 205-219

49. Schütze J, Custodio M, Efremova SM, Müller IM and Müller WEG (1999) Evolutionary relationship of Metazoa within the eukaryotes based on molecular data from Porifera. Proc. Royal Society Lond. B 266: 63-73

50. Kruse M, Müller IM and Müller WEG (1997) Early evolution of Metazoan serine/ threonine- and tyrosine kinases: Identification of selected kinases in marine sponges. Mol. Biol. Evol. 14: 1326-1334

51. WimmerW, Perovic S, Kruse M, Krasko A, Batel Rand Müller WEG(1999) Origin of the integrin-mediated signal transduction: functional studies with cell cultures from the sponge Suberites domuncula. Europ. J. Biochem. 7: 111-124

52. Dedio J, Jahnen-Dechent W, Bachmann M, Müller-Esterl W (1998) The multiligand protein $\mathrm{gC} 1 \mathrm{qR}$, putative $\mathrm{C} 1 \mathrm{q}$ receptor, is a mitochondrial protein. $\mathrm{J}$. Immunol. 160: 3534-3542

53. Pfeifer K, Haasemann M, Gamulin V, Bretting H, Fahrenholz F and Müller WEG (1993) S-type lectins occur also in invertebrates: high conservation of the carbohydrate recognition domain in the lectin genes from the marine sponge Geodia cydonium. Glycobiol. 3: 179-184

54. Blake MS, Johnston KH, Russel-Jones GJ and Gotschlich EC (1984) A rapid sensitive method for detection of alkaline phosphatase-conjugated anti-antibody on Western blots. Anal. Biochem. 136: 175-179

55. Neufeld TP and Rubin GM (1994) The Drosophila peanut gene is required for cytokinesis and encodes a protein similar to yeast putative bud neck filament proteins. Cell 77: $371-379$

56. BLAST (1997) http://www.ncbi.nlm.nih.gov/blast/blast.cgi 
57. FASTA (1997) http://www.ncbi.nlm.nih.gov/BLAST/fasta.html

58. Thompson JD, Higgins DG and Gibson TJ (1994) CLUSTAL W: improving the sensitivity of progressive multiple sequence alignment through sequence weighting, positions-specific gap penalties and weight matrix choice. Nucleic Acids Res. 22: 4673-4680

59. Felsenstein J (1993) PHYLIP, ver. 3.5. University of Washington, Seattle

60. Dayhoff MO, Schwartz RM and Orcutt BC (1978) A model of evolutionary change in protein. In: Atlas of protein sequence and structure, Dayhoff MO, ed. pp. 345352. Nat. Biomed. Res. Foundation, Washington, DC

61. Nicholas KB and Nicholas Jr HB (1997) GeneDoc: a tool for editing and annotating multiple sequence alignments. Version 1.1.004. Distributed by the author: cris.com/ ketchup/genedoc.shtml; INTERNET

62. Kyte J and Doolittle RF (1982) A simple method for displaying the hydropathic character of a protein. J. Mol. Biol. 157: 105-132

63. Mansour SJ, Skaug J, Zhao XH, Giordano J, Scherer SW and Melancon P (1999) p200 ARF-GEP1: a Golgi-localized guanine nucleotide exchange protein whose Sec7 domain is targeted by the drug brefeldin A.Proc. Natl. Acad. Sci. USA 96: 7968-7973

64. Ausubel FM, Brent R, Kinston RE, Moore DD, Smith JA, Seidmann JG and Struh K (1995) Current protocols in molecular biology. John Wiley and Sons: New York

65. Chomczynski $P$ and Sacchi N (1987) Single-step method for RNA isolation by guanidinium thiocyanate-phenol-chloroform extraction. Anal. Biochem. 162: $156-159$

66. Wiens M, Koziol C, Hassanein HMA, Batel R and Müller WEG (1998) Expression of the chaperones 14-3-3 and HSP70 induced by PCB $118\left(2,3^{\prime}, 4,4^{\prime} 5\right.$ pentachlorobiphenyl) in the marine sponge Geodia cydonium. Mar. Ecol. Prog. Ser. 165: $247-257$
67. Stanley PE and Kricka LJ (1990) Bioluminescence and chemiluminescence: current status. John Wiley, Sons, New York

68. Simpson TL (1984) The Cell Biology of Sponges, Springer-Verlag, New York

69. Schröder HC, Krasko A, Batel R, Skorokhod A, Pahler S, Kruse M, Müller IM and Müller WEG (2000) Stimulation of protein (collagen) synthesis in sponge cells by a cardiac myotrophin-related molecule from Suberites domuncula. FASEB J. 14: 2022-2031

70. Hochuli E, Döbeli H and Schacher A (1987) New metal chelate adsorbent selective for proteins and peptides containing neighbouring histidine residues. J. Chromatography 411: $177-184$

71. Laemmli UK (1970) Cleavage of structural proteins during the assembly of the head of bacteriophage T4. Nature 227: 680-685

72. Wimmer W, Blumbach B, Diehl-Seifert B, Koziol C, Batel R, Steffen R, Müller IM and Müller WEG (1999) Increased expression of integrin and receptor tyrosine kinase genes during autograft fusion in the sponge Geodia cydonium. Cell Adhesion Commun. 260: 156-165

73. Harlow Eand Lane D (1988) Antibodies: a laboratory manual. Cold Spring Harbor Laboratory: Cold Spring Harbor, NY

74. Bachmann M, Mayet WJ, Schröder HC, Pfeifer K, Meyer zum Büschenfelde K-H and Müller WEG (1986) Association of La and Ro antigen with intracellular structures in HEp-2 carcinoma cells. Proc. Natl. Acad. Sci. USA 83: 7770-7774

75. Weigele M, De Bernardo SL and Leimgruber W (1973) Fluorometric assay of secondary amino acids. Biochem. Biophys. Res. Commun. 50: 352-356 